\title{
Rising Popularity of Gig Economy: A Case Study from India
}

\author{
Baishali Pal \\ School of Management Varanasi, Malhadiya Crossing Varanasi, Uttar Pradesh, 221001, India \\ baishalipal30@gmail.com
}

ARTICLE INFO

Article history

Received 1 August 2021

Revised 20 August 2021

Accepted 25 August 2021

Keywords

Case study;

Covid-19;

Gig economy;

Indian economy.
ABSTRACT

This article raises an issue of the rising popularity of gig economy in India. A market that is based on a fixed-term contract or that is paid per project by a company, third party, or online marketplace is referred to as the "gig economy". By employing a case study approach, this article highlights the impact of gig economy in India. The gig economy's impact at work is widespread and felt across industries. It has completely transformed how people are engaged at work and has resulted in a fundamental shift in the way our economy operates. While the gig economy offers enormous benefits to workers in terms of flexibility, employment, freedom, and so on, it also has a negative impact on the industry's working environment. In both the global and Indian contexts, it has advantages and disadvantages.

This is an open access article under the CC-BY-SA license

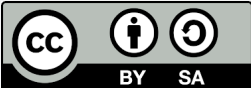

\section{Introduction}

The gig economy is all the rage these days. We are all aware of the changes in our jobs, professions, economies, and societies, from newscasters to taxi drivers to pizza delivery drivers to the unemployed. The impact of the gig economy on people's daily lives. There are now a number of In the UK, an estimated 1.1 million people work in the gig economy.

This includes delivering food, driving taxis, and providing other services. A GIG economy is a free market system in which organizations hire independent workers for short-term commitments and temporary positions are common. The term "GIG" is a slang term for a job that lasts for set amount of time and is commonly used by musicians. Work arrangements such as freelancers, independent contractors, and project-based workers are examples of GIG employees in the workforce.

In recent years, there has been a shift toward a gig economy. The rise in short-term jobs is due to a number of factors. For one thing, the workforce is becoming increasingly mobile, and work is increasingly being done remotely via digital platforms. As a result, job and location are becoming increasingly dissociated. That means freelancers can choose from a global pool of temporary jobs and projects, while employers can choose the best people for specific projects from a pool larger than what's available in any given area. The use of digital labor platforms tools that allow employers to access a pool of on-demand 
workers is becoming more common in the gig economy. One-third of all labor transactions will be mediated by digital platforms by 2025 , according to estimates. The number of people who have found work through the internet has increased dramatically around the world. Over 70 million platforms are estimated to exist [1].

By 2025, online talent platforms could benefit up to 540 million people. As many as 230 million people could find new jobs faster, reducing the length of time they are unemployed, while 200 million people who are either unemployed or working part-time could benefit. Working hours can be obtained through the use of freelance platforms. As many as 60 millions of people could find work that is more suitable for them, while having certain abilities or preferences, while another 50 million people could transition from informal to formal employment. Yet the gig economy is not without disadvantages. Some claim that gig economy causes economic disparity [2] or gender inequality in economic term [3]. This article aims to shed light on the impact of gig economy in India.

\section{Method}

The article uses case study approach that falls under qualitative research. After describing the development of gig economy, several issues in India especially relating to gig economy regulations are raised. The author would then elaborate both workers' as well as government perspectives.

The author also took into accounts events held that relates to gig economy in India. One especially is the Horasis India Meeting in July 2021. Horasis is a gathering of more than 400 Indian business leaders and their global counterparts (https://horasis.org/management/).

\section{Results and Discussions}

\subsection{History of gig economy}

According to some HR experts, jazz musicians first used the term "gig" in 1915 to refer to a job. In the year 1940, the first temp agency opened, providing temporary jobs to typists and other clerically trained employees. Along with the digital era, the gig economy began to take off in the late 1990s and early 2000s. During the 1990s, 10\% of the US workforce was employed as a consultant. As the demand for more flexible work schedules and non-permanent staff grew, so did the use of contractors, temps, and on-call workers [4]. Craigslist was launched in 1995, and it offered local San Francisco-based online classifieds for jobs, wanted and for sale items, gigs, services, resumes, housing, and more. Following that, in 1999, Upwork was launched, allowing freelancers to use the internet to find new projects and clients [5]. When the Great Recession hit in 2008, people had less secure and limited location-based work and were unable to find stable work, the gig economy gained traction.

\subsection{India and its large gig economy}

Stage work is a growing trend since internet accessibility went mainstream. Concert workers do not have the same regular hours or pay as workers in traditional positions. While much of this segment consists of individuals who are concert staff by choice, there 
are also many others who become concert staff by accident. In the case of India, for example, there are almost 500 million workers. Its largest employer is agriculture with about 200 million workers engaged in the sector. Of those who remain, many have been affected by the outbreak of the pandemic and have found new jobs in the burgeoning informal economy. In developed economies, these "contract workers" have legal rights and higher wages. Is this possible in the Indian concert sector? What would that imply? Is there any area in India that doesn't have a gig aspect?

To discuss these issues, Horasis is hosting the Horasis India Meeting on July 24, 2021. A wide range of people will participate in the one-day virtual event, including members of governments, businesses, academia, and the media. The goal is to come up with practical and long-term solutions to pressing issues as a group.

\subsection{Indian's growth and Covid 19 impact}

Individuals can market their skill sets (in both the unskilled labour market and as skilled professionals) and sell their services online through various platforms or companies in the Gig Economy. It's also known as "crowd sourcing," "sharing economy," and "collaborative".

With the downsizing of talented professionals, the rise of the digital age, where the workforce is increasingly mobile and can work from anywhere, and the effect of globalisation to create more opportunities, the Gig economy is gaining a lot of attention among the current generation of Indian professionals [6]. Today's economy has created opportunities in the global marketplace for independent contractors to expand their customer base both nationally and internationally, as well as for businesses to tap into the global market beyond their local market to obtain professional services. The Gig economy allows for more efficient services to be provided at a lower cost, such as Uber [7] or Airbnb.

COVID 19 has had a significant impact on the job market, with all major economies in recession or slowing. However, some gig workers are having difficulty finding work, while others are seeing an incre and Zomato has skyrocketed. Rather than going to a store, they ordered food and supplies to be delivered to their homes.

Gig- government and raise in job opportunities. As consumers comply with calls for quarantining, demand for delivery drivers or those who pick up food orders for online platforms such as Big Basket regulatory agencies, making it difficult to ensure that they receive government assistance .

The gig economy will continue to be relevant due to global forces. Individuals and organisations cannot afford to ignore the freelance workforce if they want to consider proactive strategies to beat the global competition. In fact, the gig economy has gained enough traction on a global scale to become a critical factor in the not-too-distant future.

Gig work is not a new phenomenon, but it has grown in popularity as a result of the pandemic. Although it has existed for a long time, official record keeping for this category only began in the last decade or so. According to a McKinsey report from 2016, an estimated 162 million people in the United States and Europe were doing some form of gig work [6]g. These were significant percentages of each region's population.' 
According to the report, gig workers can be divided into four groups: free agents, reluctants, casual earners, and those who are financially strapped. In India, a large portion of the gig economy is made up of workers who fall into the fourth category: they are financially disadvantaged.

\subsection{Can India's gig workers get legal protection?}

With the introduction of aggregator platforms, gig work gained traction. For thousands of drivers/operators, ride hailing services such as Uber and India's own Ola were a welcome opportunity. They could set their own work hours, make more daily trips, and not have to 'sign-in' if they didn't want to work.

These gig workers have become vulnerable as a result of travel restrictions that continue to affect many regions. Not only had their income source come to a halt, but they also had little in the way of social security. Many people in traditional jobs with precarious jobs had fallback options like provident fund savings. However, in the case of an Uber or Ola driver, they were left to their own devices [7].

India has a sizable informal economy. By 2024, the current administration wants India to be a $\$ 5$ trillion economy. Formalizing the informal economy was a key part of the agenda for achieving this goal. Meanwhile, according to the International Labor Organization, "informality was found in both the traditional informal and the new informal economy, as well as-increasingly-through the rise of informality in the formal sector." "Limited employment creation in the formal economy means that for many people, the only alternative is to seek employment in the informal economy," according to the report.

Almost every sector in India has a gig impact, with even the formal sector exploring informal routes, while technology platforms were able to keep a large number of gig workers employed, the current economic downturn has turned the tide against them [6]. Gig workers contracting with such companies are protesting by 'logging-out' of platforms, which are reducing their earnings and increasing the daily distances to be covered to earn bonuses.

\subsection{Collaborating for solution}

Even in developed countries, ride hailing or delivery services are only now beginning to receive social security benefits. In fact, in some cases, legislation is still only applicable to specific states or regions, rather than the entire country [8]. Because the dynamics and variables involved in India are vastly different, identical strategies cannot be implemented. However, because formulating and implementing such policies takes time, preemptive measures can be considered.

In this regard, policymakers and industry heavyweights can convene to discuss potential actions to protect this sizable contingent of gig workers. To ensure that gig workers do not fall through the cracks, social security frameworks can be discussed. Many gig workers had made steady progress in improving their socioeconomic positions prior to the pandemic. Regrettably, the pandemic has eroded much, if not all, of the gains made thus far. It's past time for India to refocus on the gig economy.

For workers, workers have little job security and few benefits because the gig economy is largely unregulated. Few argue, however, that the gig economy in India, which 
does not provide workers with social security, insurance, or other benefits, is just an extension of India's informal labour, which has existed for a long time and has remained uncontrolled. With the influx of tech companies, there is more data available, potentially enabling job security. A worker must be sufficiently skilled. Unless a person is exceptionally gifted, his bargaining power is bound to be limited. Because the labour market is largely unregulated, workers have little job security and receive fewer social security benefits such as pensions and gratuities. Employees have less bargaining power: Unless a person is exceptionally gifted, his or her bargaining power is bound to be limited. It will be difficult to organise workers into unions. For the government: Due to its flexible and dynamic nature, it is difficult to regulate.

For the government, due to its flexible and dynamic nature, it is difficult to regulate. As a result, the enforcement of tax and labour laws is largely ineffective. Companies frequently refer to their employees as 'driver-partners' or 'delivery-partners,' ostensibly to avoid any responsibility.

There are also several issues with nomenclature. Employees are entitled to minimum wages, regulated working hours, healthcare, and other benefits under the law. Independent contractors, on the other hand, do not have a valid claim to these benefits because they merely use the platform and do not work for the companies directly. This distinction has been crucial in the rise of the gig economy because it allows tech companies to avoid all labour regulations. By reorganising the relationship and classifying workers as independent contractors, companies like Uber have been able to avoid contributing to employee benefits.

As for inequality, regional disparity, people in many rural areas may be unable to participate in the gig economy due to a lack of internet access and electricity. Inequality among gig economy workers occur. People with higher skill sets (video producers, software engineers, and so on) have more bargaining power and thus earn a fair wage, whereas people in the lower strata (delivery boys, chauffeurs, and so on) do not.

\subsection{Recent step taken by Indian government}

The Ministry of labour and Employment has been working on a 'Code on Social Security, 2019' for some time. The code includes provisions to ensure that gig-economy workers receive benefits. According to the 2019 Code on Social Security, the federal or state governments may notify specific schemes for gig workers to provide various benefits, such as life and disability insurance. At state level Initiative; Karnataka has drafted a bill to ensure that workers in the gig economy, such as cab aggregators and delivery partners, have access to basic services.

\section{Conclusion}

According to the findings, Covid-19 has had a positive impact on the gig economy. Since the occurrence of Covid-19, the number of average daily tasks/jobs posted and filled on platform economy has increased. Due to the prevailing uncertainty, the Gig economy is taking time to adjust to the new normal, as the Covid-19 incident has created an extraordinary situation. The conditional variance of the OLI series increased at the start of the difficult year 2020, implying that the Gig economy has reacted to the Covid-19 
outbreak. The positive relationship between Covid-19 and the gig economy exists only in the short term, as previous study found no long-term relationship between the two variables. In addition, the impact of Covid-19 on new OLI openings its impact on OLIfilled jobs is more prominent.

The findings of this study contradict the findings of numerous previous studies that concluded that Covid-19 has only had a negative impact on stock markets and economies. Covid-19 has had a positive impact on the gig economy, just as it has on the environment. As a result, the Corona virus has not only caused devastation, but it has also had a positive impact in some areas, such as agriculture. Family life, the environment, and the gig economy are all factors to consider. In terms of future research, the forecast for the Covid19 and its impact on the gig economy can provide useful information to policymakers. Studies could also look into ways to make the transition to the gig economy as painless as possible, in order to avoid the negative consequences of a future epidemic or pandemic.

\section{References}

[1] Woodcock J, Graham M. The Gig Economy: a Critical Introduction. UK: Polity Press; 2020.

[2] Wood AJ, Graham M, Lehdonvirta V, Hjorth I. Good Gig, Bad Gig: Autonomy and Algorithmic Control in the Global Gig Economy. Work Employment, Soc 2019;33:56-75. doi:https://doi.org/10.1177/0950017018785616.

[3] Churchill B, Signe Ravn LC. Gendered and generational inequalities in the gig economy era. J Sociol 2019;55:627-36. doi:https://doi.org/10.1177/1440783319893754.

[4] Gordon Burtch, Carnahan S, Greenwood BN. Can You Gig It? An Empirical Examination of the Gig Economy and Entrepreneurial Activity. Manage Sci 2018;64:5461-959. doi:https://doi.org/10.1287/mnsc.2017.2916.

[5] Green DD, et al. Fueling the Gig Economy: A Case Study Evaluation of Upwork.com. Manag Econ Res J 2018;04:104. doi:10.18639/merj.2018.04.523634.

[6] Rao DT. "Gig Economy": A Study on Its Growing Relevance in India. Glob J Sci Res Publ 2021;1:6-9.

[7] Sanders DE, Pattison P. Worker Characterization in a gig economy viewed through an Uber centric Lens. South Law J 2016;26:297-320.

[8] Ghosh SK, Kheterpal D, Sharma S. Macroeconomic Policies and Financial Stability in India. IMI Konnect 2020;9:1-13. 